field. Crime and Punishment in Britain is still used as a textbook of criminology; two volumes, one written with Sarah McCabe, on Crime and Insanity in England, still give by far the best historical and empirical account of that topic. No forensic psychiatrist could begin to study his subject without reading these books. His latest book on Sentencing, Theory, Law, and Practice is yet another tour de force and will, no doubt, also become required reading. In his socalled retirement he is writing further books.

Outside this country he has been honoured with Visiting Professorships at Berkeley, Yale, Stockholm, and Cape Town.

Nigel's calm rationalism, tempered with humanity, has had a considerable impact on the sentencing debate in Britain. For 10 years he was on the Home Secretary's Advisory Committee on the Penal System, and many psychiatrists will know his very considerable contribution to the Butler Report on Mentally Abnormal Offenders.

Another strong theme to Nigel Walker's work has been probation and social work. He chaired the Home Secretary's Advisory Council on Probation and After-Care between 1972 and 1978; for four years he was President of the National Association of Probation Officers.

I cannot be quite sure when I first met Nigel Walker. I think it was probably on the telephone, if you see what I mean, when as an incredulous young researcher I was requested in a polite and deferential way by Nigel to play the role of expert while he gleaned a few more facts for his latest review.

Nigel is a man without pomposity, of considerable wit and charm, a man who always underestimates his own contributions. One of the things which endeared me to him before I even knew him came from the blurb of one of his books which pointed out that he was running a joint class of prisoners and graduate students in Oxford prison discussing sentencing policy!

Perhaps my warmest memories of Nigel will remain for the time during the three years he and I spent on a Howard League committee set up to discuss dangerousness which was chaired by Jean Floud, who was then Principal of Newnham College. Saturdays spent in delightful surroundings in stimulating company with superb cuisine reassured me that the academic life had its compensations after all. One of those very considerable compensations is discourse and fellowship with Nigel Walker.

Mr President I have the honour to introduce to the Honorary Fellowship of this College, Nigel David Walker, Emeritus Professor at the University of Cambridge, Doctor of Philosophy, Doctor of Letters, Doctor of Laws, Commander of the Order of the British Empire.

\title{
Letter to the President
}

\section{Dear Dr Birley}

It was a pleasure and an honour to be with you and your colleagues at the Royal College of Psychiatrists meeting in London in October. It was a very special honour for me to receive the Certificate for my Fellowship in the College and I am most appreciative.

I was also pleased to hear that the College continues its strong stand and excellent work against the use of psychiatry for political purposes. I am confident that without the work of organisations like the College I would not be free today. We must continue to work for major changes in the Soviet Union and not settle for cosmetic revisions made to satisfy the West.

Thank you again for all of the support that you and the College have given to me and to my colleagues and friends in the Soviet Union. I look forward to working with you in the future.

ANATOLY KORYAGIN

Am Brunnenbaechli 8

8125 Zollikerberg, Switzerland 